\title{
Simon Malmenvall
}

\section{(Mis)Trusting Unification: Examples of East Slavic Perception of the Council of Florence (Ne)zaupljivo zedinjenje: primeri vzhodnoslovanske-
ga sprejemanja florentinskega koncila}

Abstract: This article discusses the religious and cultural background of the ambivalent reception of the Council of Florence (1437-1439) among the East Slavic (Rus') ecclesiastical and political elite of the time, which was characterized by (mis)trust towards the late Byzantine pro-Western stance and unified Christianity under the authority of the pope. The author of this article accentuates the establishment of two separate (Orthodox) ecclesiastical and cultural centers, Kyiv and Moscow, as the main long-term consequence of the council in Eastern Europe. Here, special attention is given to the role of Isidore, the metropolitan of Kyiv, and two narrative texts from the mid-fifteenth century concerning the events during and after the council. The first is the polemical treatise Isidore's Council written by the presbyter Simeon of Suzdal, while the second is the anonymous travel diary Journey to Florence. The former is defined by its ,anti-Latin' polemical tone, which decisively influenced the later East Slavic, particularly Muscovite, perception of unionism. On the other hand, the Journey, with its lack of any theological problematization of the council decrees, represents the first East Slavic travel diary describing social and cultural features of Central and Southern Europe.

Keywords: Council of Florence, medieval ecclesiastical history, literature of Rus', Orthodoxy, unionism

Povzetek: Članek se posveča verskemu in kulturnemu ozadju dvoumnega sprejemanja florentinskega koncila (1437-1439) med takratno vzhodnoslovansko (starorusko) cerkveno in politično elito, ki je bilo obarvano z (ne)zaupanjem do Zahodu naklonjenega stališča poznega Bizanca in do zedinjenja krščanskega sveta pod papeževim vodstvom. Avtor članka poudarja vzpostavitev dveh ločenih (pravoslavnih) cerkvenih in kulturnih središč, to je Kijeva in Moskve, kot glavno dolgoročno posledico koncila na ozemlju vzhodne Evrope. Tu so posebej pozorno obravnavani kijevski metropolit Izidor in dve pripovedni besedili iz sredine 15. stoletja, ki zadevajo dogodke med in po koncilu. Prvo besedilo je 
polemični spis Izidorjev zbor, katerega avtor je duhovnik Simeon iz Suzdalja, drugo pa je anonimni potopis Potovanje v Firence. Prvo opredeljuje, protilatinska' polemična ost, ki je odločilno vplivala na kasnejše vzhodnoslovansko, zlasti moskovsko, (ne)sprejemanje uniatskega pojava. Po drugi strani Potovanje z odsotnostjo teološkega problematiziranja koncilskih odlokov predstavlja prvi vzhodnoslovanski potopis, ki prinaša oris družbenih in kulturnih značilnosti srednje in južne Evrope.

Ključne besede: florentinski koncil, srednjeveška cerkvena zgodovina, staroruska književnost, pravoslavje, uniatsko vprašanje

\section{Introduction}

This article discusses the religious and cultural background of the ambivalent reception of the Council of Florence (1437-1439) among the members of the East Slavic (Rus') ecclesiastical and political elite of the time, which was characterized by (mis)trust towards the late Byzantine pro-Western stance and unified Christianity under the authority of the pope. Similarly, the ongoing contacts with several official attempts to restore unity between the local Churches under the supreme authority of Rome and Constantinople since the so-called Great Schism of 1054, particularly after the sack of the imperial capital in 1204 at the beginning of the Fourth Crusade, were decisively marked by mutual political and theological scepticism, mostly based on deeply rooted cultural divergences and historical resentments. (Chadwick 2003) The ecclesiastical dignitaries and secular authorities involved in this process were usually unable to comprehensively reconcile the specific understandings of dogmatical definitions and disciplinary practice of the separate Churches and, in turn, trust each other in terms of readiness to (partly) hand over the control over interpretation to another, which is associated with attitudes of positive reaction (Domenicucci and Holton 2017). Using the post-modern theoretical concepts, it can be said that both sides experienced a lack of sincere dialogical engagement in seeking the truth (Osredkar 2018; Bogataj 2018, 958-959).

The author of this article argues that one of the most important long-term consequences of the council was the establishment of two separate (Orthodox) ecclesiastical and cultural centers in Eastern Europe, Kyiv in the south-west and Moscow in the north-east. In this article, special attention is given to the role of Isidore, the metropolitan of Kyiv, and two narrative texts from the mid-fifteenth century: the polemical treatise Isidore's Council written by the presbyter Simeon of Suzdal and the anonymous travel diary Journey to Florence. Both texts can be regarded as representative due to their rich content and stylistic expressivity, which enables their placement in the wider historical and cultural context pointing to the complex East Slavic attitude towards Europe and the Catholic Church. The reception of the Council of Florence among the East Slavic elite, particularly on the territory of the Great Principality of Moscow, was substantial and vibrant. Based on the disillusion- 
ment over the Byzantine ,betrayal' of the Orthodox faith and the fall of Constantinople under the rule of the Ottoman Turks in 1453, the Council of Florence strongly influenced the emergence of the notion of Moscow as the Third Rome. This notion argued for Moscow as the only independent Orthodox polity in the world, also oriented towards the unification of other Orthodox Slavic territories in Eastern Europe, and served as a justification of the subsequent creation of its first own emperor (tsar) in the person of Ivan IV (1547-1584), resembling the former Byzantine monarchs with their role of the protectors of Orthodoxy worldwide. (Kirillin 2008, 459; 467-468; Maleto 2005, 67; Malmenvall 2014, 396; Petruško 2018, 117)

The general chronological and political traits of the reception of the Council of Florence among the East Slavs are well documented in several scholarly works, such as a synthetic monograph by the British ecclesiastical historian Joseph Gill (1901-1989) (1959), a classical study on the beginnings of the unionist movement by the Polish-American historian Oscar Halecki (1891-1973) (1958), and a detailed study concerning the council's aftermath on the territory of present-day Ukraine and Belarus leading to the Union of Brest (1596) by the Ukrainian-American ecclesiastical historian Borys Gudziak (2001). The most comprehensive collection of East Slavic texts on the council is covered in the Church Slavic-Latin critical edition prepared by the Czech ecclesiastical historian Jan Krajcar (1915-1992) (1976), while the image of the lands of the ,Latin' Christendom expressed in Rus' late medieval literature is analyzed in the monograph of the Russian cultural historian Natalia Kazakova (1915-1984) (1980).

\section{Council and Roots of Unionism}

The last major development representing an attempt at the unification of the Catholic and Orthodox Churches at a general and formal level occurred at the closing of the ecumenical council in Florence (1438-1439), when a decree of union was signed by Emperor John VIII Palaeologus (1425-1448) on behalf of the ,Greek' side and Pope Eugenius IV (1431-1447) on behalf of the ,Latin' side. The principal reasons why the union was accepted by the Orthodox camp were the role of the Byzantine intellectual elite, which, due to its sympathy for Western theology, was a supporting factor in drafting compromise formulations of orthodoxy, and the rapid advance of Ottoman Turks into the central areas of Europe, which threatened the existence of Byzantium. During the first half of the fifteenth century, the Byzantine Empire was in a deep political and economic crisis: its territory was diminished to several enclaves around Thessaloniki and Constantinople, which was highly depopulated, and the province of Morea in the Peloponnesus with islands in the Marmara and Aegean Seas. From the Byzantine perspective, the union was the first step towards an expected papal call for mounting a crusade to save the Christian empire in the East. Such aid from the West never materialized; the Byzantine trust in the Western Christian world proved unfounded. (Malmenvall 2014, 387; 389; 2018, 79; Gudziak 2001, 10-11; Petruško 2018, 101) 
The greatest share of discussions at the council meetings was focused on the Filioque controversy, resulting in the adoption of a compromise solution that was closer to the Catholic view. The insertion "from the Father and the Son « was adopted as valid, while the older, and also Orthodox, formulation (»from the Father «) was countenanced as a complementary mode of expressing the same content. (Malmenvall 2014, 390; 2018, 79-80) The council activities also brought about an extensive cultural exchange. The discussions were accompanied by familiarization with the views of the opposing side and the transmission of certain works by Eastern Church Fathers and ancient pagan authors - especially Plato and Aristotle-hitherto unknown to the West, which contributed to the further development of the humanist movement. (2014, 390-391; 2018, 79-80) The Byzantine conservative majority, where the most prominent role was played by monks, rejected any change to the Niceno-Constantinopolitan Creed. The conservatives' victory was affirmed by Constantinople falling under the Ottoman rule in 1453. In their eyes, this negated the view of any political meaningfulness of the union and gave the impression, at the spiritual level, of representing ,Divine retribution' for submitting to ,Latin errors.' (2014, 395-396; 2018, 80)

The mid-fifteenth century was marked by a break in the history of the metropolitanate of Kyiv by its division into western Rus' (Ruthenian) and Muscovite (Russian) jurisdictions. Isidore (1433-1458), the metropolitan of ,Kyiv and all Rus', was, like the majority of Kyivan metropolitans during the Middle Ages, of Greek origin. He was also one of the prominent spokesmen among the Orthodox hierarchy negotiating for ecclesiastical unification with the Catholic Church prior to, during, and after the Council of Florence. Isidore came to Moscow in 1437 to represent the Church of Rus' and lead its delegation composed of bishops, priests, and laymen at the ecumenical council convocated to reach a theological and organizational accord between the patriarchal sees of Rome and Constantinople and other centers of the Christian East. Additionally, the metropolitan of Kyiv, following a previous mandate from Constantinople, signed the union decree also on behalf of Dorotheus, the absent patriarch of Antioch (1436-1454), which implies Isidore enjoyed high esteem ${ }^{1}$ within the entire Orthodox world. (Gudziak 2001, 43; 1994, 48; Gill 1964, 65-78; Petruško 2018, 105; 109)

The most acute and most persistent resistance to the Council conclusions came from Muscovy under grand prince Vasily II (1425-1462). After the Kyivan metropolitan Isidore, who was based in Moscow² and was the supreme leader of Ortho-

1 On the role of Isidore in the Orthodox Church in general and various types of reception of the Council of Florence, see: Akišin 2011.

2 The metropolitanate encompassed East Slavic Orthodox Christians; its name (,of Kyiv') perpetuated the symbolic status of Kyiv as the original political and religious center of Rus', thus emphasizing the religiouscultural unity of East Slavs (Malmenvall 2018, 80). The title ,metropolitan of Kyiv and all Rus" was first used in 1347 by the Byzantine emperor John VI Kantakouzenos (1347-1354) regarding metropolitan Theognostos (1327-1353) (Gudziak 2001, 287; Miklosich and Müller 1860, 261; 265). This title became standard at the time of metropolitan Cyprian (1390-1408). For a discussion on the evolution of the Kyivan metropolitan's title, see: Pritsak 1986. With the wider ecclesiastical territory of the Kyivan metropolitanate, divided between three polities (Muscovy, Great Duchy of Lithuania, and Kingdom of Poland), it was in the interest of each to press its case before the Patriarchate of Constantinople regarding the residence and jurisdiction of the Kyivan metropolitan. Moscow enjoyed Constantinople's favor, and 
dox Christians in Muscovy and Poland-Lithuania, celebrated the liturgy in the Kremlin in 1441 at which he commemorated the pope, Vasily accused him of heresy and had him locked away in Chudov Monastery in the Moscow Kremlin, allowing him to escape later that year. In 1448, the grand prince committed an even more daring act: without the consent of Constantinople, which the territory of the Orthodox East Slavs had belonged to in ecclesiastical terms ever since its official Christianization at the time of grand prince Vladimir Sviatoslavich (980-1015) and the establishment of the metropolitanate of Kyiv in the mid-eleventh century (Gudziak 2001, 1), he appointed a native, the Ryazan bishop lona (Jonah), as the head of the newly established metropolitanate ,of Moscow and All Rus" through elections by a council of bishops from the territory of Muscovy. This decision of the Muscovite episcopate, supported by the grand prince, was not entirely unexpected and was not meant to be schismatic since their position was also based on the fact that lona had already been sent to Constantinople in 1436 after the death of metropolitan Gerasimus (1433-1435) to become the new head of the all-Rus' Church. This stance was expressed in various letters issued by metropolitan lona and grand prince Vasily during the late 1440 s and early 1450s. However, in the meantime, Patriarch Joseph II had already pragmatically chosen Isidore, a highly educated man, an admirer of contemporary Italian humanism and public supporter of the union, while Iona was sent back to Ryazan with the promise to succeed Isidore as metropolitan after his death. The patriarch did not wish to leave the leadership of the metropolitanate of Kyiv, his richest, most populous and, in terms of territory, the vastest local Church, in the hands of a less-renowned hierarch who might not be keen to sign the politically promising accord with Rome.

On the other hand, the ecclesiastical and political dignitaries of Muscovy were encouraged by the Orthodox council in Jerusalem, where the main Middle-Eastern authorities, the patriarchs of Alexandria, Jerusalem, and Antioch, revoked the Florentine union. Furthermore, the position of Moscow and exile of Isidore received their support in 1442 by a letter of the monks of Mount Athos, which praised Vasily's resoluteness to defend the ,true' faith. The relatively late appointment of the new metropolitan was also a result of the internal political situation, as Vasily was occupied with another problem - he had to wage wars against the Tartars and local pretenders to the Muscovite throne. (Fennel 2006, 183-188; Gudziak 2001, 45; 1994, 49-50; Petruško 2018, 100-101; 103-104; 123-125; 137; Malmenvall 2018, 80)

The proclamation on establishing the new metropolitanate entailed the beginning of the autocephaly of the Church of Moscow. ${ }^{3}$ The process of autocephaly of

the patriarchate generally maintained a policy of appointing only one metropolitan for all East Slavic Orthodox lands. Consequently, for most of the fourteenth and the first half of the fifteenth centuries, the Orthodox Church in Lithuania and Poland was nominally subject to the metropolitan residing in Moscow. (Gudziak 2001, 2-3) Among the likely reasons for the patriarchate's inclination towards Moscow was the fact that, at least until the end of the fourteenth century, the Lithuanian grand princes were pagans and later converted to the Latin (Roman) branch of the Catholic Church (Meyendorff 1981, 271-272).

3 The autocephaly of the Church of Moscow was not recognized by the patriarch of Constantinople until 1589 , when it was elevated to the patriarchy of ,Moscow and all Rus'. 
the Church of Moscow, however, was not conditioned by the local aspirations to achieve ecclesiastical independence per se, but emerged as a reaction against the presupposed ,heresy' of the Constantinopolitan patriarchate and found its justification in extraordinary measures to ensure the continuation of the true and unchangeable' Orthodox Church. The new metropolitan changed his title from ,metropolitan of Kyiv and all Rus" to ,metropolitan of Moscow and all Rus". This marked an important symbolic shift, a translatio Ecclesiae of sorts. Since then, Moscow, not Kyiv, was the primary symbol of the spiritual unity of Rus' in the eyes of the Muscovite elite. Inter alia, this entailed a further deterioration of relations with the neighbouring Poland and Lithuania, ${ }^{4}$ which endeavoured to bring the same Orthodox population under their wings in political terms and subject it to the ecclesiastical jurisdiction of Rome. In order to avoid exacerbating this tension, the Polish king Casimir IV (1447-1492) recognized two East Slavic metropolitan sees in 1451: the Orthodox Moscow and the unionist Kyiv within the Polish-Lithuanian state. (Malmenvall 2014, 396; 2018, 80-81; Pliguzov 1991, 344; Petruško 2018, 100; Fennel 2006, 177-182, 186-188; Gavrilov 1958, 21-22) Similarly, in 1458 Pope Pius II (1458-1464), after the death of the unionist Constantinopolitan patriarch Gregory III Mammas (1443-1451), who in 1451 had left his see and moved to Rome due to the pressures of the conservative line of his monks and clergy, appointed Gregory II (1458-1472), a Bulgarian aide of Isidore's, as the new head of the metropolitan Church of Kyiv. According to the papal bull, the territory of the Muscovite state (Lat. Russia Superior) under the ecclesiastical jurisdiction of metropolitan lona was not considered a part of the new unionist Kyivan metropolitanate. Therefore, from the Roman perspective, the influence of the Eastern Catholic Kyivan see was perceived in a line of political realism, limited to the borders of the Polish and Lithuanian crowns. (Gudziak 1994, 50; Halecki 1956, 21; Petruško 2018, 127) $)^{5}$

\section{Two Modes of Perceiving the Council}

The Council of Florence received a strong response in the preserved East Slavic narrative texts (Kirillin 2008, 459-460). ${ }^{6}$ Among others, two texts created in Muscovy address the Council of Florence: Journey to Florence (Хождение во Флоренцию), a travel diary by an unknown Suzdalian, and Isidore's Council and His Journey (Исидоров собор и хождение его), a polemical treatise by a presbyter, Simeon of Suzdal (Kirillin 2008, 459; Krajcar 1976, 77; Droblenkova 1989, 335; Borozdin 1904, 459). Their creation can be placed between 1440 and 1460. The travel diary by the unknown Suzdalian, which was probably written before 1445, is considered the earliest of all East Slavic texts on the Council of Florence. These

4 On the chronology and political circumstances of the reception of the council in the Kingdom of Poland, see two classical works: Lewicki 1899; Chodynicki 1934.

5 This papal bull is studied in: Wawryk 1963.

6 For the main traits of Muscovy's reaction against the union of Florence, see: Krajcar 1979; Alef 1962. 
texts are accounts written by Rus' participants in the council and reflect the Muscovite elite's view on the agreed union. (Kirillin 2008, 459-460; Krajcar 1976, 3; 47; 77; 112; Gavrilov 1958, 13)

Isidore's Council is a first-person polemical treatise directed against Catholic ,conceitedness,' which was supposedly reflected in the overly prominent role of the pope and modifications to the ,pure' Christian teachings, but most of all against metropolitan Isidore, who had supposedly convinced the Rus' delegation to accept the Catholic views through bribery and threats. Isidore's Council professes a wholly different attitude towards Mark Eugenikos, the metropolitan of Ephesus; as the only hierarch at the council who did not sign the union decree, he is elevated to a personification of the fight for orthodoxy. Vasily II, the grand prince of Moscow, is presented as a parallel positive character at the secular level. This ruler plays a central role in Isidore's Council, as the work also ends with a eulogy in his honour. Simeon attributes courage and care for defending the faith of their ancestors to the grand prince, juxtaposing the steadfast Muscovite state with the unreliable Byzantine Empire. Simeon's polemical treatise thus also acts as religious and patriotic self-assertion of Muscovy within the Orthodox world. One of the major features of Isidore's Council is Simeon's apologetic stance, as he repeatedly emphasizes his non-cooperation with the Catholic side and with the Orthodox faction sympathetic to Catholicism. Simeon presents himself as a victim of Isidore's intrigue and, as such, a martyr to the ,true faith.' (Malmenvall 2018, 81-82; Gavrilov 1958, 7; 10; Droblenkova 1989, 334-336; Kazakova 1977, 47-48; Alpatov 1973, 135-138)

On the way to Italy and during the council sessions, Simeon accompanied his bishop, Abraham. By his own account, once the council had ended, he openly expressed his disagreement with Isidore's unionist standpoint while in Venice, resulting in the metropolitan having him put in jail. Simeon subsequently escaped and, at his own wish, set off for his homeland, i.e., Novgorod, ahead of the other delegation members. There he was received by bishop Evfimii (Euthymius), who soon, however, (perhaps naively) handed him over to the prince of Smolensk, Yury Semenovich-Lugvenevich, a supporter of unionist policy who was under Isidore's influence. The prince of Smolensk had Simeon put in chains and sent to Isidore, who then brought him to Moscow to grand prince Vasily II in 1441. As Isidore's unionist policy was met with resistance in Moscow, the grand prince released Simeon. Even so, the grand prince apparently considered Simeon a controversial person, as after his initial release, Vasily ,preventively' moved him to Chudov Monastery and later to the Trinity Sergius Lavra7 to the north-east of Moscow, from where Simeon again turned to Euthymius, the bishop of Novgorod, where he stayed until 1450. (Gavrilov 1958, 7-10; Droblenkova 1989, 334-335; Borozdin 1904, 458; Alpatov 1973, 134-135) The reason for this unfriendly treatment of Simeon could be his stance, emphasized in his treatise, that the Orthodox side

The Holy Trinity Lavra of Saint Sergius (Свято-Троицкая Сергиева лавра) was an extensive monastery complex and the spiritual center of Muscovy. 
had signed the union decree in Florence out of greed-in exchange for entering the union, most of the Orthodox bishops had allegedly accepted a hefty bribe from the pope (Malmenvall 2018, 83-84). Simeon's life after the Council of Florence, as described above, can lead to the conclusion that it was his unfortunate circumstances that prompted him to write Isidore's Council as an apologetic and polemical account.

Striking a completely different note in terms of genre, the Journey by the unknown Suzdalian describes the voyage of the Rus' delegation from Suzdal to Florence and back between 8 September 1437 and 29 September 1440. This literary text can be categorized as a later-type Rus' travel diary; ${ }^{8}$ this type first appeared in the fourteenth and fifteenth centuries alongside traditional pilgrims' travel diaries about holy sites, especially Jerusalem and Constantinople-its first-person narrators are no longer pilgrims, but merchants or emissaries of the state or Church. (Prokof'ev 1984, 19) The author of the travel diary in question was a member of the Muscovite delegation, either clergyman or layman, who accompanied Abraham, the bishop of Suzdal, to the Council of Florence. The travel diary by the unknown Suzdalian contains no overt polemical element reflecting a mistrust towards the Catholic Church. The author of the Journey presents the creation of the union through factual formulations, discussing it as an expected course of action. In fact, the Journey avoids discussing the Council of Florence itself-the reasons for its convocation, the theological differences, and the course of the meetings. The bulk of the text focuses on the journey of the Rus' delegation to Italy and back, and within this context, particularly on the economic and cultural characteristics of European lands and towns. Based on this, the Journey is important primarily as the first extensive Rus' literary representation of the European-Catholic world, as one of the earliest written ,encounters' between Rus' and the West. (Gavrilov 1958, 13-14; Maleto 2005, 36; 105-106; 112; 119-120; 153-157; Alpatov 1973, 139-141; Prokof'ev 1984, 11; 13) The inarticulate attitude towards the Council of Florence in the Journey is not reason enough to conclude that a (significant) part of the Muscovite elite initially met the creation of the union with neutrality or even approval. This could simply be the result of the conventions of the genre or of the author's choices in structuring the narrative. It can, however, be claimed that the union did not trouble the unknown Suzdalian enough to make him draw attention to its contentiousness contrary to the genre conventions. (Malmenvall 2018, 82-83)

In a confessional context, a significant difference between the Journey and Isidore's Council can be observed: the anonymous Suzdalian recognizes the validity of the union established at the council, thus considering both Churches spiritually equal. This is revealed in a passage of the Journey that describes the proclamation of the union in the papal liturgy in Florence. The passage reads: "And then the whole Latin council and all the people started singing and rejoicing, as

\footnotetext{
8 A thorough overview of East Slavic medieval travel diaries from the perspectives of literary theory and literary history is provided in the following monographic study: Seemann 1976.
} 
they had received forgiveness from the Greeks. " (Kirillin 2008, 480) It is quite telling that despite the lack of a polemical stance against Catholics, the Rus' travel writer perceives the council from the Orthodox point of view. Indeed, he interprets the developments as if the ,Latin' Church had returned to the ,Greek' one and thus received its forgiveness for the schism. He apparently considers the union to be an Orthodox victory and the achievement of a reconciliation benefiting both sides. (Malmenvall 2018, 85)

Contrary, Isidore's Council turns its attention to Isidore's triumphant arrival to Moscow, which supposedly agitated both the grand prince and the local clergy, on the one hand, as well as the common people, on the other (70-72). Inter alia, Simeon claims the following:

»Metropolitan Isidore came /.../ to grand prince Vasily Vasiliyevich /.../ with great Latin arrogance and injustice and conceitedness, carrying in front of him a [Catholic] cross (крыж) and a silver staff. He bore the [Catholic] cross in place of the [Orthodox] cross $(к р ь с \mathrm{~cm})$, preaching the Latin faith, and bore the staff as a symbol of Latin arrogance and conceitedness. Whoever did not kneel before the cross was struck with the staff; the order was to kneel as is done with the pope. /.../ And the pope gave him [/Isidore] much gold, and all the lands fell under papal authority, and he [Isidore] came to the land of Lithuania and to Kyiv and to Smolensk. « (70-71)

According to this text and other Muscovite polemical literature, Isidor's entry with the Latin cross is presented as a great offence (Gudziak 2001, 45). The author of Isidore's Council emphasizes that, against Isidore's expectations, the grand prince was able to see the ,deviousness' of unionist policy, as he proved himself as a brave ruler loyal to the faith of his ancestors (Krajcar 1976, 72). After that, Simeon's report on the rejection of Isidore's intentions turns into a eulogy in honour of the grand prince. He highlights Vasily's extraordinariness also by comparing him to the first Christian Roman emperor, Constantine the Great, and grand prince Vladimir Sviatoslavich, who introduced Christianity as the state religion of Kyivan Rus' in the late tenth century. (73) Simeon concludes the eulogy by drawing a contrast between the spiritually weak Byzantium, which fell into the grasp of the union, and the steadfast Orthodox Muscovy, which can be characterized as an expression of patriotic and religious self-assertion of his homeland (Malmenvall 2018, 87-88).

\section{Council and Itinerary across Europe}

The anonymous travel writer acts as the first-person narrator of his work. He starts his travel diary by mentioning that "at the birth of Holy Theotokos [8 September 1437], metropolitan Isidore departed from Moscow, came to Tver /.../, accompanied by bishop Abraham of Suzdal « (Hoždenie 1999, 464; 572). The delegation, led by Isidore, then arrives to Novgorod, where it is ceremoniously received and hosted by bishop Euthymius $(464 ; 572)$. From there, they depart for the 
Baltic lands, the territory of the Teutonic Order of knights $(464 ; 466 ; 572)$. There, they are ceremoniously received and hosted by a Catholic bishop ${ }^{9}$ from Dorpat $(466 ; 572)$. Then the Rus' delegation arrives in Riga, where it is ceremoniously received and hosted by the local archbishop $(466 ; 572)$. After that, the delegation arrives in the north German city of Lübeck on 19 May, the name day of the martyr Patrikios $(466 ; 468 ; 572) .{ }^{10}$ The travel writer then indulges in fascination with the splendours of this city.

"And we saw the splendid city and there were /.../ lovely gardens and splendid palaces, gilded roofs, and its monasteries are splendid and big. And it is full of merchandise of any kind. There are waters routed to the city, flowing in all streets through pipes, while others [flow] over towers, cool and fresh. And [Isidore] visited churches on the Feast of the Ascension, and we saw gold and silver liturgical objects and an abundance of saints' relics. And monks visited and started inviting the lord [Isidore] to go see their monastery. He went and they showed him an unutterable abundance of liturgical objects and an abundance of valuable golden garments with precious stones and pearls. /.../ And they led us to their refectory and brought various wines and many different appetizing dishes, while they showed great honor to the lord [Isidore] here.« $(468 ; 470 ; 572)$

In general, ,waters' are the aspect of European cities the travel writer expresses most admiration for, mentioning it most frequently (concerning canals, waterworks, fountains, etc.). All this is likely to have been a new experience for him. It is thus possible to assume that care for , waters' in the towns of Muscovy was less technically developed at the time. (Malmenvall 2018, 88)

The next major stop is the city of Nuremberg. When the travel writer describes Nuremberg, he distinguishes between the land or territorial political unit (земля), the language or linguistic community (языкъ) and the religion (вьра), comparing the linguistic-cultural characteristics to the Slavic world known to him. "And this city of Nuremberg stands in the middle of the Alamannian land. The Alamannian land does not have another faith nor another language, but the same Latin faith, and the language [there] is German, though different; as are the Rus' in relation to the Serbs, such are they [/the Alamannians] in relation to the Germans." (472) After that, the delegation arrives in Augsburg. The travel writer claims this city "surpasses all the previously described cities in size" (472). The next stop is Innsbruck, near which the delegation members cross the Alps and then descend to the Italian town of Pavia, from where they arrive to Ferrara, where the first part of the council meetings takes place $(472 ; 573)$.

9 This and all the subsequent mentions of the hospitality of ,Latins' towards Orthodox Christians show that despite doctrinal differences, personal relations between Catholic and Orthodox representatives were not hostile, but stiff at worst.

10 The route through the Baltic lands to modern-day northern Germany was the central transport link between Eastern, Central, and Northern Europe in the Middle Ages and the early modern era (Maleto 2005, 93). 
The anonymous author then describes Ferrara, where he is enthralled the most about a mechanical angel holding a trumpet in the clock tower in the main town square (474). The travel writer then reports on the relocation of the council from Ferrara to Florence. The description of Florence is the climax of the anonymous Journey-not only because of the central event, i.e., the formation of the union, but also because of the splendid appearance of the city, which seems to surpass all the others. "This renowned city of Florence is very big, unlike anything we had seen in the previously described cities. It has magnificent and big churches and it has palaces built of white rock, very tall and skillfully [built].« (476; 573) After describing the sights of the city, he focuses his attention on the formation of the union and, in this context, also describes the liturgy during which the union was ceremoniously proclaimed:

»With him [/the pope] [there were] twelve cardinals and ninety-three bishops /.../. The Greek emperor, John, who sat in the appointed place, watched their service, and all boyars with him; and here in the appointed places sat the metropolitans along with all the clergy. ${ }^{11} / . . . /$ And after the service, the pope and his people started chanting a prayer, and after the prayer, he sat in the middle of the council on a tall, gilded throne prepared for him, and a pulpit had been raised near him. And among the Latins, a cardinal named Julian [Giuliano Cesarini] stood up, along with the Nicene metropolitan, Bessarion [among the Greeks], and they brought the council documents, and Julian started reading the Latin document aloud, and then the metropolitan started reading the Greek document. And when the reading of the documents was done, the pope blessed the people.« $(478 ; 480 ; 573)$

After that, the travel writer reports that on 6 September 1439, the Rus' delegation set off for home, first heading to Venice (480). The author again expresses his enthusiasm about European cities, this time for Venice, about which he writes, inter alia:

"This city stands on the sea; there is no dry road to it, as it stands on the sea thirteen miles from shore [/land]. It is crossed by ships and craft, and all streets are full of water; they move around by boat. This city is very large and has splendid palaces, some gilded. And it is full of merchandise of any kind, as it is frequented by ships from every land /.../. This city has a stone church of Saint Mark the Evangelist, which has stone columns of colorful marble of all kinds, and the icons there are magnificent.« $(480 ; 482 ; 574)$

This is followed by the final part of the travel diary describing the way home. The travel writer first mentions sailing from Venice to Parenzo (Poreč), then a land route from Parenzo to Pola (Pula) on the Istrian peninsula, and from there a sea voyage

11 The travel writer conveys the message that the concluding liturgy by the altar was conducted by the ,Latin' side, while the Orthodox one, which supposedly only observed the event, apparently found itself in a symbolically subordinate position. 
to Senj, from where the delegation arrives by land to Brinje in modern-day Lika, Croatia. Here, the travel writer explicitly mentions Croats, comparing them to his own people: "And these towns are populated by Croats [ховратянь]; their language is like that of the Rus' [Pycb], and their faith is Latin." (482) Then the travel writer mentions the route via Modruš and Jastrebarsko to Zagreb, about which he writes: "This city is large and splendid. This [city] is under the authority of the Hungarian tsar [/king]. And in this city, we saw the Serbian tsar despot ${ }^{12}$ with his tsarina and children; his tsardom had been conquered by the Turkish tsar, Murat." (482; $484 ; 574)$ After that, the travel writer mentions the route from Zagreb to the Drava river, leading through Križevci and Koprivnica. Here he writes the following: "There is a mile between Koprivnica and the Drava river. This river is located on the border between the Slavic/Slovene [словьньска земля] and the Hungarian [угорьска земля] lands. " (484) The travel writer goes on to mention the route from Szeged to Budapest and then to their destination, Suzdal. He pays no particular attention to towns on the way from Budapest to Suzdal, mostly only enumerating them. It can thus be assumed that these towns were of no interest for the travel diary, as he probably considered them already familiar to Rus' readers.

\section{Conclusion}

Isidore's Council by the Suzdalian presbyter Simeon and the Journey by an unknown Suzdalian are first-person accounts that are key to understanding the attitude of the (ecclesiastical) elite of late medieval Muscovy towards Europe and the Catholic Church. Among the earliest texts on the Council of Florence created in the Muscovite territory in the mid-fifteenth century, these accounts stand out for their comprehensive content as well as for the difference in genre between them. Thus, they complement both Latin and Greek writings about the council and therefore attach even greater international importance to this event, also lending a diverse literary expression to its reception. With its, anti-Latin' polemical stance and the praise of Muscovy, Isidore's Council had a decisive impact on the later East Slavic perception of the council and of the related issue of unionism. The anonymous Journey, on the other hand, represents the first East Slavic travel diary focusing on the economic and cultural characteristics of Catholic Central and Southern Europe.

Although theological considerations were not irrelevant, it was primarily the political context in Muscovy that conditioned the resolutely negative response and polemics. The Grand Principality of Moscow could not be favourable towards unionism, primarily due to its association with the long-lasting rivalry with Lithuania, which had, like the emerging state of Moscow, territorial aspirations over East Slavic polities and had been, since the end of the fourteenth century, officially part of the Catholic Church. This contrasted with the attitude towards Flor-

12 The despot in question is Đurađ (George) Branković (1427-1457), who had been defeated by the Ottoman sultan Murat II (1421-1451), which marked the end of the existence of the medieval Serbian state. 
ence in the lands of present-day Ukraine and Belarus. The ambivalence in the (reduced) Kyivan metropolitanate towards the confessional divide was clear in the post-Florence decades. (Gudziak 2001, 49; Petruško 2018, 116-117)

After the death of Iona, the new Moscow metropolitan Theodosius (1461-1465) used the shortened title ,metropolitan of all Rus', dropping the suspicious invocation of (temporarily) unionist Kyiv and, presumably, recognizing the practical inability, although not the (nominal) aspirations, to unify all East Slavic Orthodox Christians, in order to exert his jurisdiction over the (former) Eastern Orthodox lands within the Grand Duchy of Lithuania and Kingdom of Poland. On the other hand, Gregory, the (uniate) metropolitan of Kyiv, declared his allegiance not only to Rome but also to Constantinople, writing a petition to the patriarch seeking his approval to renew the jurisdiction of the metropolitan Church over all East Slavic lands as it had been before the division caused by the council. In February 1467, in a transitional period before the official and final rejection of the Florentine union by patriarch Simeon I (1482-1486), patriarch Dionisius I (1466-1471) granted Gregory's request and confirmed him as the only all-Rus' hierarch and Kyiv as the reunified metropolitan see, at the same time reprimanding the Muscovite bishops and lona for causing ecclesiastical and territorial division. (Gudziak 1994, 51; Ščapov 1976, 145-147; Petruško 2018, 150) In practice, the existing borders between the two metropolitan sees stayed in force following the political division until the beginning of the sixteenth century.

It is also worth mentioning that the Church of Kyiv, from its emergence in the mid-eleventh century until the early modern period, was rarely involved in theological disputes between Rome and Constantinople, the only noteworthy exceptions being several tracts ${ }^{13}$ against Latin ,heresies' translated from Greek in the twelfth century-moreover, their authors were mostly of non-Slavic origin, Kyivan metropolitans or monks coming from Byzantium. A clearer attitude of the ecclesiastical intellectuals on the territory of present-day Ukraine and Belarus towards the Catholic Church and its unionist endeavours, either pro or contra, was established only around and after the union of Brest in 1596. (Gudziak 1994 52) Furthermore, one of the most important long-lasting consequences of the Council of Florence on the East Slavic late medieval and early modern culture can be recognized in the gradual decline of the ,all-Rus" ethnocultural sense of identity, which had survived the political disintegration of Kyivan state at the beginning of the thirteenth century. It had been fostered without interruption by the ecclesiastical elites, accentuating the perception of the common faith with a common Church Slavonic liturgical-literary language and members of the common Rurikid dynasty confessing Eastern Orthodoxy, since the official Christianization within a unified East Slavic (Kyivan) metropolitanate. In the council's aftermath, two diverse East Slavic ethnocultural communities began to emerge-Muscovite (Russian) in the north-east and Ruthenian (Western Rus') in the south-west, the latter serving as

13 On anti-Latin polemics in the Kyivan Rus', see: Podskalsky 1982, 170-185; Senyk 1993, 298-326; Danilevskij 2018. 
a basis, although in very different social circumstances, of the subsequent modern Ukrainian and Belarus nations. (Plokhy 2006, 104; 134-136; 146-149; 153; 157159; 162-163; Lur'e 2009)

\section{References}

Akišin, Sergej J. 2011. Mitropolit Isidor Kievskij i problema cerkovnoj unii v pozdnej Vizantii. Vestnik Ekaterinburgskoj duhovnoj seminarii 1:70-101.

Akišin, Sergej J., and Boris N. Florja. 2011. Isidor. In: Pravoslavnaja éncilopedija. Vol. 27, 177182. Moscow: Cerkovno-naučnyj centr Pravoslavnaja énciklopedija.

Alef, Gustave. 1962. Muscovy and the Council of Florence. Slavic Review 20, no. 3:389-401.

Alpatov, Mihail A. 1973. Russkaja istoričeskaja mysl' i Zapadnaja Evropa 12-17 vv. Moscow: Nauka.

Bogataj, Jan D. 2018. Neopatristična sinteza in ressourcement: med tradicijo in postmoderno. Bogoslovni vestnik 78, št. 4:957-969.

Borozdin, Aleksandr K. 1904. Simeon, ieromonah Suzdal'skij. In: Russkij biografičeskij slovar'. Edited by Aleksandr A. Polovcov. Vol. 18, 458459. Saint Petersburg: Imperatorskoe russkoe istoričeskoe obščestvo.

Chadwick, Henry. 2003. East and West: The Making of a Rift in the Church: From Apostolic Times until the Council of Florence. Oxford: Oxford University Press.

Chodynicki, Kazimierz. 1934. Kościół prawosławny a Rzeczpospolita Polska: Zarys historyczny 1370-1632. Warsaw: Instytut Popierania Nauki.

Danilevskij, Igor' N. 2018. Antilatinskaja polemika na Rusi v XI-XII vekah. In: Vitaliy Nagirnyy, ed. Colloquia Russica 8: Religions and Beliefs of Rus' (9th-16th Centuries), 115-129. Kraków: Uniwersytet Jagielloński.

Domenicucci, Jacopo, and Richard Holton. 2017. Trust as a Two-Place Relation. In: Paul Faulkner and Thomas Simpson, eds. The Philosophy of Trust, 149-160. Oxford: Oxford University Press.

Droblenkova, Nadežda F. 1989. Simeon Suzdal'skij. In: Slovar' knižnikov i knižnosti Drevnej Rusi. Edited by Dmitrij S. Lihačëv. Vol. 2. Part 2, 334-336. Leningrad: Nauka.

Fennell, John. 2006. A History of the Russian Church to 1448. New York: Longman.

Gavrilov, Mihail N. 1958. Ferraro-florentijskij sobor i Rus'. New York:v Fordham University Press.
Gill, Joseph. 1959. The Council of Florence. Cambridge: Cambridge University Press.

- - - 1963. Isidore's Encyclical Letter from Buda. Analecta Ordinis Sancti Basilii Magni 2, no. 2/4:1-8.

- - - 1964. Personalities of the Council of Florence and Other Essays. Oxford: Oxford University Press.

Gudziak, Borys. 1994. Grec'kyj shid, Kyivs'ka mitropolija i Florentijs'ka unija. Zapysky naukovogo tovarystva imeni Ševčenka 228:48-64.

---. 2001. Crisis and Reform: The Kyivan Metropolitanate, the Patriarchate of Constantinople, and the Genesis of the Union of Brest. Harvard, MA: Harvard University Press; Ukrainian Research Institute.

Halecki, Oskar. 1956. The Ecclesiastical Separation of Kiev from Moscow in 1458. In: Günther Stöckl, ed. Studien zur älteren Geschichte Osteuropas: Festschrift für Heinrich Felix Schmid, 19-32. Graz: Hermann Böhlaus Nachfolger.

- - - 1958. From Florence to Brest (1439-1596). New York: Fordham University Press.

Hoždenie. 1999. Hoždenie na Florentijskij sobor. In: Biblioteka literatury Drevnej Rusi. Edited by Dmitrij S. Lihačëv. Vol. 6, 464-487; 571-574. Translated by Natalija A. Kazakova. Moscow: Institut russkoj literatury.

Kazakova, Natalija A. 1977. Evropejskie strany v zapiskah russkih putešestvennikov 15 . veka. Voprosy istorii 33, no. 6:37-48.

- - - 1980. Zapadnaja Evropa v russkoj pis'mennosti 15-16 vekov. Leningrad: Nauka.

Kirillin, Vladimir N. 2008. Hoždenie na Ferraro-Florentijskij sobor. In: Istorija drevnerusskoj literatury: analitičeskoe posobie, 459-468. Moscow: Jazyki slavjanskoj kul'tury.

Krajcar, Jan, ed. 1976. Acta Slavica Concilii Florentini: Concilium Florentinum documenta et scriptores. Vol. 11. Rome: Pontificum institutum orientalium studiorum.

- - - 1979. Simeon of Suzdal's Account of the Council of Florence. Orientalia Christiana Periodica 39, no. 1:103-130.

Lewicki, Anatol. 1899. Unia Florenska w Polsce. Kraków: Nakł. Akademii Umiejętności. 
Lur'e, Vadim M. 2009. Russkoe pravoslavie meždu Kievom in Moskvoj. Moscow: Tri kvadrata.

Maleto, Elena I. 2005. Antologija hoženij russkih putešestvennikov 12-15 veka. Moscow: Nauka.

Malmenvall, Simon. 2014. Florentinski koncil (1438-1439): uspehi in neuspehi reševanja uniatskega vprašanja. Bogoslovni vestnik 74, no. 3:385-397.

- - - 2018. Vzhodnoslovanski literarni pričevanji o florentinskem koncilu in slovensko ozemlje. Primerjalna književnost 41, no. 3:77-97.

Meyendorff, John. 1981. Byzantium and the Rise of Russia: A Study of Byzantino-Russian Relations in the Fourteenth Century. Crestwood, NY: St. Vladimir's Seminary Press.

Miklosich, Franz, and Iwan Müller. 1860. Acta patriarchatus Constantinopolitani. Vol. 1. Vienna: Gerold.

Osredkar, Mari J. 2018. V začetku je bil dialog. Bogoslovni vestnik 78, no. 1:17-31.

Petruško, Vladislav I. 2018. Florentijskaja unija, Moskovskij sobor 1441 goda i načalo avtokefalii Russkoj Cerkvi. Cerkov' i vremja 82, no. 1:99-168.

Pliguzov, Andrei. 1991. On the Title, Metropolitan of Kiev and All Rus". Harvard Ukrainian Studies 15:340-353.

Plokhy, Serhii. 2006. The Origins of the Slavic Nations: Premodern Identities in Russia, Ukrai$n e$, and Belarus. Cambridge: Cambridge University Press.
Podskalsky, Gerhard. 1982. Christentum und theologische Literatur in der Kiever Rus' (9881237). Munich: C. H. Beck.

Pritsak, Omeljan. 1986. Metropolitan of Kiev and all Rus': The Fate of a Sacral Idea. Harvard Ukrainian Studies 10, no. 3-4:279-300.

Prokof'ev, Nikolaj I. 1984. Kniga hoženij: Zapiski russkih putešestvennikov 11-15 vv. Moscow: Sovetskaja Rossija.

Seemann, Klaus D. 1976. Die altrussische Wallfahrtsliteratur: Theorie und Geschichte eines literarischen Genres. Munich: Fink.

Senyk, Sophia. 1993. A History of the Church in Ukraine. Vol. 1, To the End of the Thirteenth Century. Rome: Pontificio istituto Orientale.

Ščapov, Jaroslav N. 1976. Vostočnoslavjanskie $i$ južnoslavjanskie rukopisnye knigi v sobranijah Pol'skoj Narodnoj Respubliki. Vol. 2. Moscow: Institut istorii SSSR.

Wawryk, Michael. 1963. Quaedam nova de provisione metropoliae Kioviensis et Moscoviensis ann. 1458. Analecta Ordini Sancti Basilii Magni 4, no. 1:9-26. 